International Journal of Advanced Biological and Biomedical Research Available online at http:www.ijabbr.com

Volume 8, Issue 2 (2020) pp. 146-152

DOI: 10.33945/SAMI/IJABBR.2020.2.5

Original Article

\title{
Effect of Crop Residue and Nitrogen Level in Yield and Yield Attributing Traits of Rice under Rice-Wheat Cropping System
}

\section{Narayan Khatri ${ }^{1, *}$, Nabin Rawal2 ${ }^{2}$ Devraj Chalise ${ }^{3}$, Mamata Bista $^{4}$, Bisheshwor Prasad Pandey ${ }^{1}$}

${ }^{1}$ National Wheat Research Program, Bhairahawa, Rupandehi, Nepal

${ }^{2}$ Soil Science Division, Khumaltar, Nepal

${ }^{3}$ National Maize Research Program, Rampur, Chitwan, Nepal

${ }^{4}$ Regional Agriculture Research Station, Lumle, Kaski, Nepal

*Corresponding Author E-mail: narayan.iaas068@gmail.com

Received: 24 August 2019, Revised: 12 October 2019, Accepted: 17 October 2019

\begin{abstract}
A 3 years (2015, 2016 and 2017) field study was carried out at National Wheat Research Program, Bhirahawa, Rupandehi, Nepal to evaluate the influence of crop residues and nitrogen levels on rice. The experiment was conducted in split plot design with three replications. Main plots were two crop residue levels (with crop residue and without crop residue) and sub plots consisted of seven nitrogen levels $(0,25,50,75,100,125$ and $150 \mathrm{~kg}$ $\mathrm{N} \mathrm{ha}^{-1}$ ). Combined analysis of three years data revealed that crop residue levels did not differ significantly in terms of grain yield; however, crop residues incorporation increased the rice grain yield slightly. Significant difference was observed with application of different nitrogen levels in grain yield and yield attributing characters viz; tillers $\mathrm{m}^{-2}$, panicle length, number of filled grains per panicle and thousands grain weight. Rice grain yield was found at increasing rate with the increased level of nitrogen @ $150 \mathrm{~kg} \mathrm{ha}^{-1}$. Application of nitrogen @ $150 \mathrm{~kg} \mathrm{ha}^{-1}$ gave highest grain yield of $4831 \mathrm{~kg} \mathrm{ha}^{-1}$ which was found at par with nitrogen @ $125 \mathrm{~kg} \mathrm{ha}^{-1}$ with grain yield of $4722 \mathrm{~kg} \mathrm{ha}^{-1}$. Crop residues with nitrogen @ $125 \mathrm{~kg} \mathrm{ha}^{-1}$ resulted in $216 \mathrm{~kg} \mathrm{ha}^{-1}$ higher rice grain yield than residues removed treatment. The overall conclusion drawn from the three years field experiment was an improved crop residue management with $125 \mathrm{~kg} \mathrm{~N} \mathrm{ha}^{-1}$ increased the grain yield of rice.
\end{abstract}

Key words: Crop residue, Nitrogen levels, Rice, Yield

\section{Introduction}

In recent years, use of combined harvester for harvesting and threshing of rice and wheat crop has been increasing in Western Terai region of Nepal. The crop residue left over after harvesting of previous corp by using combined harvester is major concern to manage for planting succeeding crops under rice-wheat cropping system. So, farmers are compelled to 
burn such huge amount of crop residues. Burning of wheat residues is cost effective and the predominant method of disposal in areas under combined harvesting in the Indo Gangetic Plains (Samra et al., 2003). However, disposal of crop residues by burning is no longer environmentally acceptable and often criticized for accelerating losses of soil organic matter and nutrients, increasing $\mathrm{C}$ emissions and reducing soil microbial activity (Kumar and Goh, 2000).

Crop residues incorporation can improve soil quality and reduce air pollution on a longterm basis. However, where residues have been soil incorporated, farmers often have concerns for reduced soil fertility from nutrient immobilization and problems for cultivation associated with slow rates of residues decomposition (Cookson et al., 1998). Effective mitigation of these effects depends on developing crop residue management strategies that enhance residues decomposition. Realizing the potential benefits of cereal residues incorporation depends on synchronizing the release of $\mathrm{N}$ with the crop demands, while minimizing the risks to nutrient losses (Powlson et al., 1985; Hooker et al., 1982). Where residue has been incorporated before planting the next crop, grain yield was lower than where residues were removed or burned, resulting in $\mathrm{N}$ immobilization (Bahrani et al., 2002; Singh et al., 2004). The most influential factor on wheat yield is $\mathrm{N}$ fertilization, although the degree of influence is governed principally by weather conditions and residual soil N (Garrido-lestache et al., 2005). Hence, this study was conducted to determine the effect of crop residue and nitrogen level on growth and yield of rice under rice-wheat cropping system.

\section{Materials and methods}

The field experiment was conducted in three cropping seasons of 2015, 2016 and 2017 at National Wheat Research Program (NWRP), Bhairahawa, Nepal and the field was laid out in split plot design: two crop residue levels (with and without residue) as whole plot and seven nitrogen levels $\left(0,25,50,75,100,125\right.$ and $\left.150 \mathrm{~kg} \mathrm{ha}^{-1}\right)$ as sub-plot which were replicated three times. The rice variety was sabitri and transplanted at the spacing of $20 \mathrm{~cm}$ $\times 20 \mathrm{~cm}$. The plot size was $5 \mathrm{~m} \times 3 \mathrm{~m}$. Urea, single super phosphate and muriate of potash were the source of fertilizers used for supplying nitrogen, phosphorus and potash respectively. Full dose of phosphorus ( $\left.30 \mathrm{~kg} \mathrm{P}_{2} \mathrm{O}_{5} \mathrm{ha}^{-1}\right)$, potassium fertilizers $\left(30 \mathrm{~kg} \mathrm{~K}_{2} \mathrm{O} \mathrm{ha}^{-}\right.$ 1 ), and half dose of nitrogen was applied at the time of land preparation. Whole Crop residues were retained in the field as natural residues after wheat harvesting. The remaining half dose of Nitrogen was top-dressed in two equal splits viz; first at active tillering and second at panicle initiation stage.

Before harvest, plant height, panicle length and tillers $\mathrm{m}^{-2}$ of rice were recorded. After harvest, filled grains per panicle, 1000 grain weight and grain yield were recorded. Average plant height and panicle length were recorded from five sample plants. Average number of filed grains per panicle was counted from five panicles for each treatment. Grain yield was measured from $8 \mathrm{~m}^{2}$ area. Grain yield was adjusted to $14 \%$ moisture content determined according to Yoshida (1981). Ten panicles were randomly collected from each plot to determine 1000 grain weight and number of filled grains per panicle.

\section{Statistical analysis}

Data were analyzed through GENSTAT statistical package and treatment means were compared using least significant difference (LSD) test at $\mathrm{P} \leq 0.05$. 


\section{Results and discussion}

\section{Effect of crop residue}

Results revealed that yield and yield components were significantly affected by nitrogen levels but crop residue had no significant effects on yield and yield components of rice during three cropping seasons (Table 1). Three years combined data analysis showed that incorporation of crop residue slightly increased plant height, panicle length, tillers $\mathrm{m}^{-2}$, filled grains panicle ${ }^{-1}, 1000$ grain weight and grain yield. This suggests that there was positive role of wheat residue in increasing rice yield as compared to without residue condition. The higher yield under residue incorporation might be due to the faster rate of decomposition of wheat straw due to high temperature and longer window between wheat residue incorporation and rice transplanting. Results obtained showed that both rice and wheat residues can be safely incorporated without any detrimental effects on the crops of rice or wheat grown immediately after incorporation.

Table 1. Effect of crop residue and nitrogen level on yield and yield components of rice under ricewheat cropping system ( 3 years pooled analysis)

\begin{tabular}{|c|c|c|c|c|c|c|}
\hline Treatments & $\begin{array}{c}\text { Plant } \\
\text { height } \\
\text { (cm) }\end{array}$ & $\begin{array}{l}\text { Panicle } \\
\text { length } \\
\text { (cm) } \\
\end{array}$ & $\begin{array}{c}\text { Tillers } \\
\mathbf{m}^{-2}\end{array}$ & $\begin{array}{c}\text { Filled } \\
\text { grains } \\
\text { panicle-1 }\end{array}$ & $\begin{array}{c}1000 \\
\text { grain wt } \\
\text { (gm) }\end{array}$ & $\begin{array}{c}\text { Grain yield } \\
\left(\mathrm{kg} \mathrm{ha}^{-1}\right)\end{array}$ \\
\hline \multicolumn{7}{|l|}{ Crop Residue } \\
\hline $\begin{array}{l}\text { Without crop } \\
\text { residue }\end{array}$ & 98 & 16 & 226 & 109 & 21 & 4182 \\
\hline With crop residue & 99 & 17 & 242 & 111 & 22 & 4183 \\
\hline F-Test & ns & ns & ns & ns & ns & ns \\
\hline \multicolumn{7}{|l|}{ LSD $(0.05 \%)$} \\
\hline \multicolumn{7}{|c|}{ Nitrogen Level (N kg ha-1) } \\
\hline 0 & 90 & 13 & 187 & 98 & 19 & $\overline{3258}$ \\
\hline 25 & 94 & 15 & 210 & 97 & 20 & 3676 \\
\hline 50 & 96 & 15 & 227 & 108 & 21 & 3952 \\
\hline 75 & 98 & 17 & 244 & 114 & 22 & 4393 \\
\hline 100 & 102 & 18 & 252 & 117 & 22 & 4445 \\
\hline 125 & 103 & 18 & 262 & 118 & 23 & 4722 \\
\hline 150 & 106 & 19 & 259 & 117 & 23 & 4831 \\
\hline F-test & $* *$ & $* *$ & $* *$ & $* *$ & $* *$ & $* *$ \\
\hline LSD $(0.05 \%)$ & 2.3 & 1.4 & 39.9 & 6.7 & 1.1 & 231.3 \\
\hline \multicolumn{7}{|l|}{ Year } \\
\hline 2014 & 91 & 13 & 215 & 108 & 21 & 3600 \\
\hline 2015 & 97 & 16 & 247 & 104 & 22 & 4324 \\
\hline 2016 & 107 & 20 & 242 & 118 & 22 & 4623 \\
\hline F-test & $* *$ & $* *$ & $* *$ & $* *$ & ns & $* *$ \\
\hline LSD $(0.05 \%)$ & 1.8 & 1.1 & 15.2 & 4.9 & & 126.7 \\
\hline CV \% & 4.1 & 14.9 & 14.9 & 10.2 & 10.9 & 6.9 \\
\hline
\end{tabular}

${ }^{*},{ }^{* *}$ and ns indicates significant levels at $0.05,0.01$ and non significant 
Application of rice residue to wheat typically has a small effect on wheat yields during the short term of 1-3 years (Singh et al., 2008; Singh et al., 2005) but the effect appears in the fourth year with the incorporation of straw (Gupta et al., 2007). Similarly, Khatri et al., (2017) reported that after two year completion of experiment, biological yield of wheat increased significantly in rice crop residue incorporation treatment.

\section{Effect of nitrogen}

Plant height, panicle length, tillers $\mathrm{m}^{-2}$, filled grains panicle-1, 1000 grain weight and grain yield of rice significantly increased with increased N rates. Grain yield is a function of interplay of various yield components such as number of productive tillers, panicle length, percentage of grain filling and 1000 grain weight (Hassan et al., 2003). Application of nitrogen @ $150 \mathrm{~kg} \mathrm{ha}^{-1}$ resulted in significantly highest grain yield and yield components (Table 1), which was found statistically at par with the application of nitrogen @ $125 \mathrm{~kg} \mathrm{ha}^{-1}$. The increased grain yield with $125 \mathrm{~kg} \mathrm{~N}^{-1}$ might be due to the cumulative effect of the highest number of effective tillers $\mathrm{m}^{-2}, 1000$ grain weight and filled grains panicle-1 obtained from the supply of nitrogen for the plants. Similar results were found previously (Singh et al., 2000; Salahuddin et al., 2009). Whereas lowest yield and yield components were obtained from $0 \mathrm{~kg} \mathrm{~N}^{-1}$ treatments.

\section{Year wise comparison of grain yield}

In the first year, rice yield was found lowest under no crop residues incorporation and grain yield and yield components were found at increasing rate with cropping season increment (Figure 1), which is similar to (Rieger et al., 2008) for no crop residue treatment. During third cropping season, yield was recorded highest of $4633 \mathrm{~kg} \mathrm{ha}^{-1}$ under crop residue incorporation. Short-term effects of cereal residues (wheat straw) incorporation into paddy field include stimulation of $\mathrm{CH}_{4}$ emissions, immobilization of available $\mathrm{N}$, suppression of rice growth, and accumulation of toxic materials (Singh et al., 2005; Singh et al., 2008).

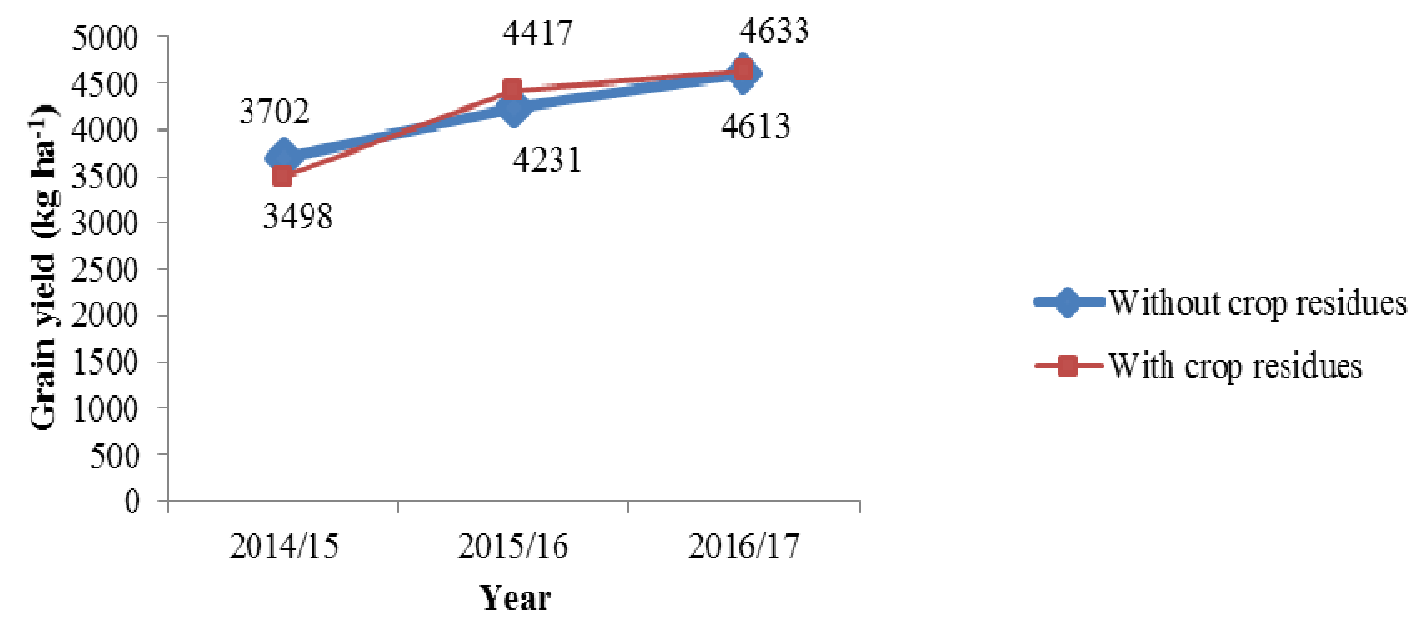

Figure 1. Year wise comparison of grain yield of rice as influenced by crop residues 


\section{Interaction effect of crop residue and nitrogen level}

The interaction between crop residue and nitrogen level treatment were investigated in Figure 2. The grain yield of rice increased by increasing $\mathrm{N}$ levels in both without crop residue and with crop residue treatments. However, higher grain yield was obtained in crop residue incorporation treatment. Incorporation of crop residue into the soil with $150 \mathrm{~kg} \mathrm{~N}$ ha-1 gave the highest grain yield in rice of $4884 \mathrm{~kg} \mathrm{ha}^{-1}$ which was found at par with nitrogen rate of $125 \mathrm{~kg} \mathrm{ha}^{-1}$ (4830 kg ha-1). Crop residues with nitrogen @ $125 \mathrm{~kg} \mathrm{ha}^{-1}$ resulted in $216 \mathrm{~kg} \mathrm{ha}^{-1}$ higher rice grain yield than residues removed treatment. Incorporation of crop residue into soil without $\mathrm{N}$ application gave the lowest grain yield of rice. This may be attributed to the soil $\mathrm{N}$ imbalance due to the slower decomposition (Figure 2).

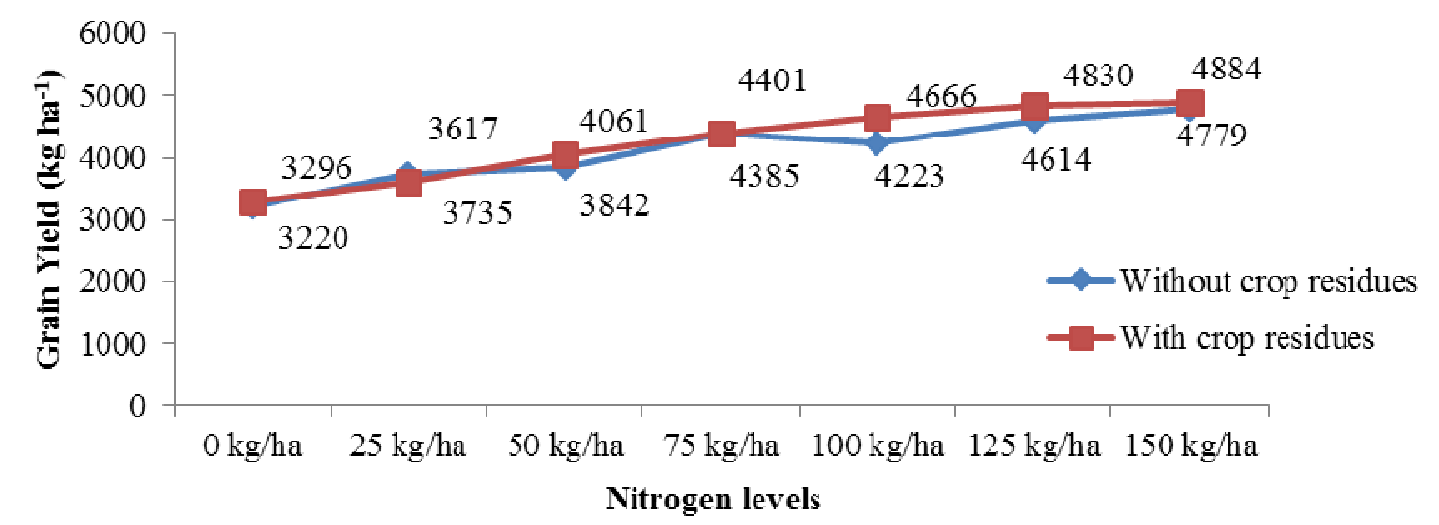

Figure 2. Interaction effect of Crop residues and Nitrogen levels on grain yield of rice (3 years Pooled analysis)

\section{Conclusion}

From the results of the present study, it can be concluded that $125 \mathrm{~kg} \mathrm{~N}^{\mathrm{N}} \mathrm{a}^{-1}$ along with crop residue incorporation may be used to obtain the highest grain yields of rice under rice-wheat cropping system. Thus, farmers are suggested to incorporate crop residues with nitrogen dose of $125 \mathrm{~kg} \mathrm{ha}^{-1}$ into the soil instead of burning; which is environmentally hazardous to human and soil health.

\section{Conflict of interest}

Authors declare no conflict of interest. 


\section{References}

Bahrani, MJ, Kheradnam, M, Emam, Y, Ghadiri, H, Assad, MT. (2002). Effect of tillage methods on wheat yield and yield components in continuous wheat cropping. Exp. Agric., 38:389-395.

Cookson, WR, Beare, MH, Wilson, PE. (1998). Residue quality and management effects on microbial properties and crop residue decomposition. Appl. Soil Ecol., 7:179-188.

Garrido-Lestache, E, Lopez-Bellido, RJ, Lopez-Bellido, FJ. (2005). Durum wheat quality under Mediterranean conditions as affected by $\mathrm{N}$ rate, timing and splitting, $\mathrm{N}$ form and $\mathrm{S}$ fertilization. Eur. J. Agron., 23:265-278.

Gupta, RK, Singh, Y, Ladha JK, Singh, B, Singh, J, Singh, G, Pathak, H. (2007). Yield and phosphorus transformations in a rice-wheat system with crop residue and phosphorus management. Soil Sc. Soc. Am. J., 71:1500-1507.

Hassan, G, Khan, NU, Khan, QN. (2003). Effect of transplanting date on the yield and yield components of different rice cultivars under high temperature of D.I. Khan. Sci. Khy., 16: 129-137.

Hooker, ML, Heroon, GM, Penas, P. (1982). Effect of residue burning, removal and incorporation on irrigated cereal crop yield and soil chemical properties. Soil Sci. Soc. Am. J., 46:122-126.

Khatri, N, Chalise, DR, Rawal, N. (2017). Short term effect of crop residue and different nitrogen levels on grain yield of wheat under rice-wheat system. Int. J. Environ. Agric. Biotech., 2(4): 1689-1693.

Kumar, K, Goh, KM. (2000). Crop residue management: Effects on soil quality, soil nitrogen dynamics, crop yield, and nitrogen recovery. Adv. Agron., 68:197-319.

Powlson, DS, Jenkinson, DS, Pruden, G, Johnston, AE. (1985). The effect of straw incorporation on the uptake of nitrogen by winter wheat. J. Sci. Food Agric., 36:26-30.

Rieger, S, Richner, W, Streit, B, Frossard, E, Liedgens, M. (2008). Growth, yield, and yield components of winter wheat and the effects of tillage intensity, preceding crops, and $\mathrm{N}$ fertilization. Eur. J. Agron., 28:405-411.

Salahuddin, KM, Chowhdury, SH, Munira, S, Islam, MM, Parvin, S. (2009). Response of nitrogen and plant spacing of transplanted Aman rice. Bangladesh J. Agric. Res., 34(2):279-285.

Singh, B, Shan, YH, Johnson, SE, Singh, Y, Buresh, RJ. (2008). Crop residue management for lowland rice-based cropping systems in Asia. Adv. Agron., 98:118-199.

Singh, MK, Thakur, R, Verma, UN, Upasani, RR, Pal, SK. (2000). Effect of planting time and nitrogen on production potential of Basmati rice (Oryza sativa L). cultivars in Bihar Plateau. Indian J. Agron., 45(2):300-303.

Singh, Y, Singh, B, Timsina, J. (2005). Crop residue management for nutrient cycling and improving soil productivity in rice-based cropping systems in the tropics. Adv. Agron., 85:269407. 
Singh, YS, Singh, B, Ladha, JK, Khind, CS, Khera, TS, Bueno, CS. (2004). Effects of residue decomposition on productivity and soil fertility in rice-wheat rotation. Soil Sci. Soc. Am. J., 68:854-864.

Yoshida, S. (1981). Fundamentals of rice crop science. Los Baños, Philippines: IRRI.

How to cite this article: Narayan Khatri*, Nabin Rawal, Devraj Chalise, Mamata Bista, Bisheshwor Prasad Pandey, Effect of Crop Residue and Nitrogen Level in Yield and Yield Attributing Traits of Rice under Rice-Wheat Cropping System. International Journal of Advanced Biological and Biomedical Research, 2020, 8(2), 146-152. Link: http://www.ijabbr.com/article_36905.html 